\title{
CISATRACURIUM VS. ROCURONIUM: A PROSPECTIVE, COMPARATIVE, RANDOMIZED STUDY IN ADULT PATIENTS UNDER TOTAL INTRAVENOUS ANAESTHESIA
}

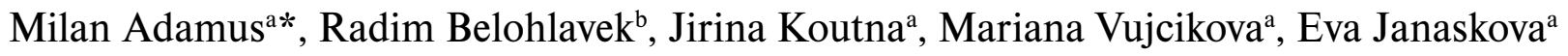 \\ a Department of Anaesthesiology and Intensive Care Medicine, University Hospital and Faculty of Medicine, \\ Palacky University, Olomouc, Czech Republic \\ ${ }^{b}$ Department of Computer Science, Palacky University, Olomouc, Czech Republic \\ e-mail:milan.adamus@seznam.cz
}

Received: October 20, 2006; Accepted: November 10, 2006

Key words: Neuromuscular block/Cisatracurium/Rocuronium/Clinical duration/Onset time/Recovery index

\begin{abstract}
Aims: To compare the pharmacodynamics of cisatracurium and rocuronium-induced neuromuscular block following single dose, allowing either spontaneous or neostigmine-accelerated complete recovery.

Methods: Following the ethics committee approval and informed consent, 120 patients scheduled for elective surgery under TIVA with tracheal intubation were randomized into 4 groups with different cisatracurium (CIS, 0.10 or $0.15 \mathrm{mg} \cdot \mathrm{kg}^{-1}$ ) or rocuronium (ROC, 0.60 or $0.90 \mathrm{mg} \cdot \mathrm{kg}^{-1}$ ) doses administered. For each patient, the onset time for $95 \%$ depression of $\mathrm{T}_{1}$, clinical duration until $25 \%$ recovery, recovery index ( $\mathrm{T}_{1}$ from 25 to $75 \%$ ) and time from $\mathrm{T}_{1}$ $25 \%$ to TOF-ratio 0.9 were determined allowing either spontaneous or induced recovery.

Results: The onset times were 277 (SD 58), 220 (46), 91 (16) and 77 (16) s for the CIS 0.10, CIS 0.15, ROC 0.60 and ROC 0.90 groups $(p<0.05)$, respectively, with lower variability in both ROC groups $(p<0.05)$. The clinical durations were 42 (7), 52 (7), 35 (11) and 52 (12) min, respectively ( $p<0.05$ for lower doses). Recovery index was identical in all groups allowing either spontaneous recovery - 15.9 (1.8), 15.5 (1.7), 16.1 (3.7) and 16.1 (4.0) min, or following neostigmine administration - $4.4(0.9), 4.5(0.8), 4.3(0.8)$ and $4.7(0.7)$ min for respective groups. During spontaneous recovery, the variability of DUR25-TOF90 was twice as great for ROC than CIS groups $(\mathrm{p}<0.05)$, while after neostigmine administration it was uniform in all groups.

Conclusions: For equipotent doses, the onset times for CIS were approximately three times longer than for ROC. The average clinical duration for both relaxants ranged from 35 to 52 min with acceptable variability. Neostigmine administration accelerated the recovery and reduced its variability. When allowing for spontaneous recovery, less scatter was demonstrated for both CIS groups than for ROC ones.
\end{abstract}

\section{INTRODUCTION}

For many years, much effort has been made to develop neuromuscular blocking agents (NMBAs, neuromuscular blockers [NMBs], muscle relaxants, curarimimetics) with rapid onset and short duration of action ${ }^{1}$. Two current drugs have this aim. Cisatracurium and rocuronium are non-depolarizing NMBs with an intermediate duration of action. They were introduced into clinical practice ${ }^{2,3}$ in 1992 (rocuronium) and 1995 (cisatracurium), respectively, and currently they are gradually replacing earlier drugs (vecuronium and atracurium). Acting on the nicotinic receptors of the neuromuscular plate, all NMBs attack one of the vital functions (spontaneous breathing) that must be simultaneously supported with mechanical ventilation of the lungs.

Almost exclusively anaesthetists use muscle relaxants; hence thorough knowledge of NMBs pharmacokinetics and pharmacodynamics is mandatory for this group of doctors.

The aim of this study was to compare the pharmacodynamic parameters of cisatracurium (CIS) and rocuronium
(ROC) induced neuromuscular block (NMB) following a single dose of 2 or $3 \times \mathrm{ED}_{95}$, allowing either spontaneous or neostigmine-induced complete recovery. Special attention was paid to the variability of these parameters.

\section{MATERIAL AND METHODS}

Following approval from the local Ethics Committee and obtaining informed consent, 120 adult patients, scheduled for elective general surgery under total intravenous anaesthesia (TIVA) with tracheal intubation, muscle relaxation and mechanical ventilation, were studied. Exclusion criteria were ASA physical status more than III, age under 18 and over 75 years, obesity (BMI over > $30 \mathrm{~kg} \cdot \mathrm{m}^{-2}$ ), patients receiving medication known to interfere with NMBs (anticonvulsants, amino glycosides or polypeptide antibiotics), patients with anticipated difficult intubation (Mallampati score ${ }^{4}$ III and more), and those with diseases affecting neuromuscular transmission (myopathies). 
Table 1. Demographic data.

\begin{tabular}{|c|c|c|c|c|}
\hline & $\begin{array}{l}\text { CIS } 0.10 \\
(n=30)\end{array}$ & $\begin{array}{l}\text { CIS } 0.15 \\
(n=30)\end{array}$ & $\begin{array}{c}\mathrm{ROC} 0.60 \\
(n=30)\end{array}$ & $\begin{array}{c}\text { ROC } 0.90 \\
(n=30)\end{array}$ \\
\hline Age (years) & $\begin{array}{c}51.5(12.6) \\
{[53.5]}\end{array}$ & $\begin{array}{c}50.6(13.3) \\
{[53.0]}\end{array}$ & $\begin{array}{c}51.5(14.9) \\
{[51.0]}\end{array}$ & $\begin{array}{c}50.9(13.7) \\
{[51.5]}\end{array}$ \\
\hline Men/Women (n) & $14 / 16$ & $16 / 14$ & $12 / 18$ & $17 / 13$ \\
\hline Weight (kg) & $\begin{array}{c}76.5(14.3) \\
{[79.5]}\end{array}$ & $\begin{array}{c}75.1(10.8) \\
{[75.0]}\end{array}$ & $\begin{array}{c}74.5(12.2) \\
{[77.0]}\end{array}$ & $\begin{array}{c}74.1(11.1) \\
{[72.5]}\end{array}$ \\
\hline Height $(\mathrm{cm})$ & $\begin{array}{c}171.1(8.2) \\
{[173]}\end{array}$ & $\begin{array}{c}170.7(7.8) \\
{[170]}\end{array}$ & $\begin{array}{c}171.3(9.0) \\
{[171]}\end{array}$ & $\begin{array}{c}171.7(8.8) \\
{[174]}\end{array}$ \\
\hline $\operatorname{BSA}\left(\mathrm{m}^{2}\right)$ & $\begin{array}{c}1.90(0.22) \\
{[1.96]}\end{array}$ & $\begin{array}{c}1.88(0.16) \\
{[1.89]}\end{array}$ & $\begin{array}{c}1.88(0.19) \\
{[1.89]}\end{array}$ & $\begin{array}{c}1.87(0.16) \\
{[1.88]}\end{array}$ \\
\hline BMI $\left(\mathrm{kg} \cdot \mathrm{m}^{-2}\right)$ & $\begin{array}{c}26.01(3.72) \\
{[26.36]}\end{array}$ & $\begin{array}{c}25.82(3.50) \\
{[26.72]}\end{array}$ & $\begin{array}{c}25.35(3.56) \\
{[25.57]}\end{array}$ & $\begin{array}{c}25.16(3.82) \\
{[25.82]}\end{array}$ \\
\hline ASA classification (I/II/III) & $11 / 16 / 3$ & $9 / 19 / 2$ & $12 / 14 / 4$ & $9 / 18 / 3$ \\
\hline
\end{tabular}

Data are means (SD - standard deviation) [median] or frequencies, CIS and ROC - groups with different doses $\left(\mathrm{mg} . \mathrm{kg}^{-1}\right)$ of cisatracurium and rocuronium administered

Pre-anaesthetic questionnaire was used to collect patients' demographic data - gender, age, weight, height, ASA classification; derived parameters (body mass index, body surface area) were computed ${ }^{5}$. Patients were randomly assigned to 4 groups of 30 (CIS 0.10 , CIS 0.15 , ROC 0.60, ROC 0.90). A method of computer-generated random numbers with blockwise randomization was used to obtain balanced sample sizes in all groups. In CIS groups, patients received cisatracurium 0.10 and $0.15 \mathrm{mg} . \mathrm{kg}^{-1}$, respectively. In ROC groups, the respective rocuronium doses were 0.60 and $0.90 \mathrm{mg} \cdot \mathrm{kg}^{-1}$.

\section{Anaesthesia}

Premedication consisted of diazepam 5-10 mg orally $1 \mathrm{hr}$ before the beginning of surgery. On arrival in the operating room, the electrocardiogram (ECG), haemoglobin oxygen saturation $\left(\mathrm{SpO}_{2}\right)$ and non-invasive arterial pressure (NIBP) were monitored. An intravenous cannula was inserted into a forearm vein. Datex-Ohmeda $\mathrm{S} / 5^{\mathrm{TM}}$ Anaesthesia Monitor with relevant modules (ECG, NIBP, pulse oxymetry, oxygen and nitrous oxide inspiratory and exspiratory concentrations, spirometry, core and skin temperature, NMT - neuromuscular transmission) was used to monitor the patient during anaesthesia and surgery.

After 3 min preoxygenation, intravenous premedication with midazolam (Dormicum ${ }^{\circledR}$, F. HoffmannLaRoche, $0.05 \mathrm{mg} \cdot \mathrm{kg}^{-1}$ ) and sufentanil (Sufenta ${ }^{\circledR}$ forte, Janssen Pharmaceutica, $0.1 \mu \mathrm{g} . \mathrm{kg}^{-1}$ ) was injected into a rapidly running infusion of normal saline. Total intra- venous anaesthesia (TIVA) in TCI mode (target controlled infusion) was induced and maintained with the Base Primea $^{\circledR}$ (Fresenius Vial) infusion device. Target plasmatic concentrations were initially set to $2.0 \mu \mathrm{g} \cdot \mathrm{ml}^{-1}$ for propofol (Propofol Abbott, Abbott Laboratories) in Schnider's model $^{6}$ and 1.8 ng. $\mathrm{ml}^{-1}$ for sufentanil in Gepts's model ${ }^{6}$, respectively, and adjusted according to clinical response during anaesthesia.

Sufentanil was discontinued 20 min before the end of anaesthesia and tracheal extubation was not performed before full recovery from neuromuscular block (TOF-ratio $\geq 0.90$ ).

\section{Neuromuscular block and monitoring}

To facilitate tracheal intubation, neuromuscular block was induced with a single bolus dose of cisatracurium or rocuronium, respectively. The calculated amount of relaxant was injected over $5 \mathrm{~s}$ into a rapid infusion of normal saline. Following maximal depression of $\mathrm{T}_{1}$ (onset time), direct laryngoscopy was initiated followed by tracheal intubation. The endotracheal tube was connected to closed „low-flow" anaesthetic breathing circuit with a mixture of $40 \%$ oxygen in air; mechanical ventilation was adjusted to maintain end-tidal partial pressure of carbon dioxide $\left(\mathrm{E}_{\mathrm{T}} \mathrm{CO}_{2}\right)$ between 4.7 and $5.0 \mathrm{kPa}$.

Neuromuscular transmission monitoring complied with GCRP (good clinical research practice) ${ }^{7,8}$, using the NMT module of Datex-Ohmeda $\mathrm{S} / 5^{\mathrm{TM}}$ Anaesthesia Monitor. Both oesophageal and skin temperature were 
Table 2. Pharmacodynamic parameters and variability - onset time, clinical duration.

\begin{tabular}{|l|c|c|c|c|}
\hline & $\begin{array}{c}\text { CIS 0.15 } \\
(n=30)\end{array}$ & $\begin{array}{c}\text { CIS 0.15 } \\
(n=30)\end{array}$ & $\begin{array}{c}\text { ROC 0.60 } \\
(n=30)\end{array}$ & $\begin{array}{c}\text { ROC 0.90 } \\
(n=30)\end{array}$ \\
\hline $\begin{array}{l}\text { ONSET TIME } \\
(\mathrm{s})\end{array}$ & $\begin{array}{c}\mathrm{B}, \mathrm{C}, \mathrm{D} \\
(58)[283]\end{array}$ & $\begin{array}{c}\mathrm{A}, \mathrm{C}, \mathrm{D} \\
220(46)[220]\end{array}$ & $\begin{array}{c}\mathrm{A}, \mathrm{B}, \mathrm{D} \\
91(16)[90]\end{array}$ & $\begin{array}{c}\mathrm{A}, \mathrm{B}, \mathrm{C} \\
77(16)[75]\end{array}$ \\
\hline $\begin{array}{l}\text { Variability of ONSET TIME } \\
(\mathrm{s})\end{array}$ & $\begin{array}{c}\mathrm{C}, \mathrm{D} \\
44)[33]\end{array}$ & $\begin{array}{c}\mathrm{C}, \mathrm{D} \\
35(29)[30]\end{array}$ & $\begin{array}{c}\mathrm{A}, \mathrm{B} \\
11(11)[10]\end{array}$ & $\begin{array}{c}\mathrm{A}, \mathrm{B} \\
12(11)[8]\end{array}$ \\
\hline $\begin{array}{l}\text { CLINICAL DURATION DUR25 } \\
(\text { min })\end{array}$ & $\begin{array}{c}\mathrm{B}, \mathrm{C}, \mathrm{D} \\
42(7)[40]\end{array}$ & $\begin{array}{c}\mathrm{A}, \mathrm{C} \\
52(7)[52]\end{array}$ & $35(11)[34]$ & $52(12)[53]$ \\
\hline $\begin{array}{l}\text { Variability } \\
\text { of CLINICAL DURATION }(\mathrm{min})\end{array}$ & $6(3)[6]$ & $\begin{array}{c}\mathrm{D} \\
5(4)[4]\end{array}$ & $8(7)[5]$ & $\begin{array}{c}\mathrm{B} \\
10(7)[9]\end{array}$ \\
\hline
\end{tabular}

Data are means (SD - standard deviation) [median], CIS and ROC - groups with different doses (mg. $\left.\mathrm{kg}^{-1}\right)$ of cisatracurium and rocuronium administered ONSET - onset time, DUR25 - clinical duration ${ }^{\mathrm{A}} \mathrm{p}<0.05$ vs. CIS $0.10,{ }^{\mathrm{B}} \mathrm{p}<0.05$ vs. CIS $0.15,{ }^{\mathrm{C}} \mathrm{p}<0.05$ vs. ROC $0.60,{ }^{\mathrm{D}} \mathrm{p}<0.05$ vs. ROC 0.90

continuously recorded. Thenar skin temperature was monitored using a probe placed on the dorsum of the hand from which the response to ulnar nerve stimulation was recorded. Skin temperature over the thenar muscles was maintained above $34{ }^{\circ} \mathrm{C}$ throughout the study period by wrapping the arm in cotton wool. After induction, but before administration of the neuromuscular blocking drug, the NMT monitor was calibrated using the automatic start-up-procedure, and we then applied $0.1 \mathrm{~Hz}$ single twitch stimulation before relaxant injection. After maximal neuromuscular block had been established, we switched to TOF stimulation assessed at $12 \mathrm{~s}$ intervals by stimulation of ulnar nerve with four rectangular impulses at $2 \mathrm{~Hz}$, duration $0.2 \mathrm{~ms}$ and supramaximal current. The evoked electromyographic response of adductor pollicis muscle was monitored. All data reflecting the effect of neuromuscular blocker (TOF-ratio, $\mathrm{T}_{1}$ value) were wirelessly transferred ${ }^{9}$ to a $\mathrm{PC}$, displayed on the screen and stored for further processing.

For each consecutive patient, spontaneous recovery until $25 \%$ of $\mathrm{T}_{1}$ was allowed (clinical duration). At this point, each group was divided into 2 subgroups of 15 patients (the randomization described previously). While in the SPONT subgroup, the patients were allowed to recover from the block spontaneously, in the NEOST subgroup the recovery course was accelerated with neostigmine (Syntostigmin, Hoechst-Biotika, 0.04 mg.kg-1) administered with atropine (Atropin, Hoechst-Biotika, $0.015 \mathrm{mg} \cdot \mathrm{kg}^{-1}$ ). The following pharmacodynamic parameters were measured in all patients:

1. ONSET TIME $(\mathrm{s})=$ time interval from the completion of the intravenous injection of the relaxant to maximal $\mathrm{T}_{1}$ depression

2. DUR25 $(\min )=$ CLINICAL DURATION - time interval from the completion of the intravenous injection of the relaxant to spontaneous recovery of $\mathrm{T}_{1}$ to $25 \%$ of the control value

3. DUR25-75 $(\mathrm{min})=$ RECOVERY INDEX - time interval from the end of clinical duration $\left(\mathrm{T}_{1}=25 \%\right)$ to $75 \%$ recovery of $\mathrm{T}_{1}\left(\mathrm{~T}_{1}=75 \%\right)$

4. DUR25-TOF90 $(\mathrm{min})=$ interval from the end of clinical duration $\left(\mathrm{T}_{1}=25 \%\right)$ to TOF-ratio 0.90 , which reflects complete recovery from the block

5. For each drug, the VARIABILITY of all pharmacodynamic parameters was determined by subtracting the actual value of a given parameter from its respective mean. The larger the variability of a parameter the less accurate was the prediction of duration of this parameter.

\section{Statistical support}

Statistical calculations were carried out using the software packages SPSS for Windows v. 14.0, Systat SigmaStat for Windows v. 3.5 and Systat SigmaPlot for Windows v. 10.0. The sample size was determined by performing a power analysis based on a previous study ${ }^{9}$. From the data, we calculated that 29 patients in each group would be sufficient to find a significant difference of $30 \%$ or more in onset time between groups ( 0.05 two-way significance level $[\alpha=0.05], 80 \%$ power $[\beta=0.2])$. Depending on the character and distribution of the data, a variety of parametric and nonparametric tests were used for statistical analysis. To compare the physical characteristics of the groups, analysis of variance (ANOVA) or Kruskall-Wallis test were performed. The chi-square test was used to compare distribution by sex and ASA classification. The pharmacodynamic variables between two groups with different doses of the same relaxant administered were compared using unpaired Student's t-test or Mann-Whitney rank sum test; analysis of variance (ANOVA) was applied when comparing all groups. If the overall comparison revealed 
Table 3. Pharmacodynamic parameters and variability - recovery characteristics.

\begin{tabular}{|c|c|c|c|c|c|c|c|c|}
\hline & \multicolumn{2}{|c|}{$\begin{array}{l}\text { CIS } 0.10 \\
(n=30)\end{array}$} & \multicolumn{2}{|c|}{$\begin{array}{l}\text { CIS } 0.15 \\
(n=30)\end{array}$} & \multicolumn{2}{|c|}{$\begin{array}{l}\text { ROC } 0.60 \\
(n=30)\end{array}$} & \multicolumn{2}{|c|}{$\begin{array}{c}\text { ROC } 0.90 \\
(n=30)\end{array}$} \\
\hline & $\begin{array}{l}\text { SPONT } \\
(n=15)\end{array}$ & $\begin{array}{l}\text { NEOST } \\
(n=15)\end{array}$ & $\begin{array}{l}\text { SPONT } \\
(n=15)\end{array}$ & $\begin{array}{l}\text { NEOST } \\
(n=15)\end{array}$ & $\begin{array}{l}\text { SPONT } \\
(n=15)\end{array}$ & $\begin{array}{l}\text { NEOST } \\
(n=15)\end{array}$ & $\begin{array}{l}\text { SPONT } \\
(n=15)\end{array}$ & $\begin{array}{l}\text { NEOST } \\
(n=15)\end{array}$ \\
\hline & $\mathrm{B}, \mathrm{D}, \mathrm{F}, \mathrm{H}$ & $\mathrm{A}, \mathrm{C}, \mathrm{E}, \mathrm{G}$ & $\mathrm{B}, \mathrm{D}, \mathrm{F}, \mathrm{H}$ & $\mathrm{A}, \mathrm{C}, \mathrm{E}, \mathrm{G}$ & $\mathrm{B}, \mathrm{D}, \mathrm{F}, \mathrm{H}$ & $\mathrm{A}, \mathrm{C}, \mathrm{E}, \mathrm{G}$ & $\mathrm{B}, \mathrm{D}, \mathrm{F}, \mathrm{H}$ & $\mathrm{A}, \mathrm{C}, \mathrm{E}, \mathrm{G}$ \\
\hline $\begin{array}{l}\text { RECOVERY INDEX } \\
\text { DUR25-75 } \\
(\min )\end{array}$ & $\begin{array}{l}15.9 \\
(1.8) \\
{[16.3]}\end{array}$ & $\begin{array}{c}4.4 \\
(0.9) \\
{[4.7]}\end{array}$ & $\begin{array}{c}15.5 \\
(1.7) \\
{[15.5]}\end{array}$ & $\begin{array}{c}4.5 \\
(0.8) \\
{[4.7]}\end{array}$ & $\begin{array}{c}16.1 \\
(3.7) \\
{[15.7]}\end{array}$ & $\begin{array}{c}4.3 \\
(0.8) \\
{[4.3]}\end{array}$ & $\begin{array}{c}16.1 \\
(4.0) \\
{[16.3]}\end{array}$ & $\begin{array}{c}4.7 \\
(0.7) \\
{[4.6]}\end{array}$ \\
\hline & F,H & & & G & $\mathrm{F}, \mathrm{H}$ & $\mathrm{A}, \mathrm{E}, \mathrm{G}$ & $\mathrm{D}, \mathrm{F}, \mathrm{H}$ & $\mathrm{A}, \mathrm{E}, \mathrm{G}$ \\
\hline $\begin{array}{l}\text { Rariability of } \\
\text { RECOVERY INDEX } \\
\text { (min) }\end{array}$ & $\begin{array}{l}1.5 \\
(0.8) \\
{[1.6]}\end{array}$ & $\begin{array}{c}0.8 \\
(0.4) \\
{[0.8]}\end{array}$ & $\begin{array}{l}1.3 \\
(1.1) \\
{[1.1]}\end{array}$ & $\begin{array}{c}0.7 \\
(0.4) \\
{[0.5]}\end{array}$ & $\begin{array}{l}2.8 \\
(2.3) \\
{[1.9]}\end{array}$ & $\begin{array}{c}0.6 \\
(0.5) \\
{[0.6]}\end{array}$ & $\begin{array}{c}3.1 \\
(2.3) \\
{[2.9]}\end{array}$ & $\begin{array}{c}0.6 \\
(0.5) \\
{[0.5]}\end{array}$ \\
\hline & B,D,F,H & $\mathrm{A}, \mathrm{C}, \mathrm{E}, \mathrm{G}$ & B,D,E,F,H & $\mathrm{A}, \mathrm{C}, \mathrm{E}, \mathrm{G}$ & $\mathrm{B}, \mathrm{C}, \mathrm{D}, \mathrm{F}, \mathrm{G}, \mathrm{H}$ & $\mathrm{A}, \mathrm{C}, \mathrm{E}, \mathrm{G}$ & $\mathrm{B}, \mathrm{D}, \mathrm{E}, \mathrm{F}, \mathrm{H}$ & $\mathrm{A}, \mathrm{C}, \mathrm{E}, \mathrm{G}$ \\
\hline $\begin{array}{l}\text { DUR25-TOF90 } \\
(\min )\end{array}$ & $\begin{array}{l}49.2 \\
(8.0) \\
{[49]}\end{array}$ & $\begin{array}{l}11.5 \\
(2.8) \\
{[12]}\end{array}$ & $\begin{array}{l}52.5 \\
(7.0) \\
{[54]}\end{array}$ & $\begin{array}{l}11.7 \\
(2.7) \\
{[12]}\end{array}$ & $\begin{array}{c}43.1 \\
(13.1) \\
{[41]}\end{array}$ & $\begin{array}{l}9.8 \\
(2.0) \\
{[10]}\end{array}$ & $\begin{array}{c}56.7 \\
(12.9) \\
{[56]}\end{array}$ & $\begin{array}{l}10.0 \\
(2.7) \\
{[10]}\end{array}$ \\
\hline & F & $\mathrm{E}, \mathrm{F}, \mathrm{G}$ & $\mathrm{F}$ & $\mathrm{E}, \mathrm{F}, \mathrm{G}$ & $\mathrm{B}, \mathrm{D}, \mathrm{F}, \mathrm{H}$ & $\mathrm{A}, \mathrm{B}, \mathrm{C}, \mathrm{D}, \mathrm{E}, \mathrm{G}$ & $\mathrm{B}, \mathrm{D}, \mathrm{F}, \mathrm{H}$ & $\mathrm{E}, \mathrm{G}$ \\
\hline $\begin{array}{l}\text { Variability of } \\
\text { DUR25-TOF90 (min) }\end{array}$ & $\begin{array}{c}6.3 \\
(4.5) \\
{[5.8]}\end{array}$ & $\begin{array}{c}2.3 \\
(1.4) \\
{[1.5]}\end{array}$ & $\begin{array}{c}5.2 \\
(4.5) \\
{[3.5]}\end{array}$ & $\begin{array}{c}2.2 \\
(1.3) \\
{[2.0]}\end{array}$ & $\begin{array}{l}10.7 \\
(7.1) \\
{[8.9]}\end{array}$ & $\begin{array}{c}1.6 \\
(1.3) \\
{[1.1]}\end{array}$ & $\begin{array}{l}10.6 \\
(6.9) \\
{[9.7]}\end{array}$ & $\begin{array}{l}1.9 \\
(1.9) \\
{[1.1]}\end{array}$ \\
\hline
\end{tabular}

Data are means (SD - standard deviation) [median],

CIS and ROC - groups with different doses $\left(\mathrm{mg} . \mathrm{kg}^{-1}\right)$ of cisatracurium and rocuronium administered DUR25-75 - recovery index, DUR25-TOF90 - time interval from the end of clinical duration ( $\mathrm{T}_{1} 25 \%$ ) to TOF-ratio 0.9, SPONT - spontaneous recovery, NEOST - neostigmine-induced recovery ${ }^{\mathrm{A}} \mathrm{p}<0.05$ vs. CIS 0.10 SPONT, ${ }^{\mathrm{B}} \mathrm{p}<0.05$ vs. CIS 0.10 NEOST, ${ }^{\mathrm{C}} \mathrm{p}<0.05$ vs. CIS 0.15 SPONT, ${ }^{\mathrm{D}} \mathrm{p}<0.05$ vs. CIS 0.15 NEOST, ${ }^{\mathrm{E}} \mathrm{p}<0.05$ vs. ROC 0.60 SPONT, ${ }^{\mathrm{F}} \mathrm{p}<0.05$ vs. ROC 0.60 NEOST, ${ }^{\mathrm{G}} \mathrm{p}<0.05$ vs. ROC 0.90 SPONT, ${ }^{\mathrm{H}} \mathrm{p}<0.05$

a statistical significance, appropriate post hoc tests were done. The results are expressed as means (SD - standard deviation) [median] or frequencies. The accepted significance level was 0.05 .

\section{RESULTS}

120 patients were enrolled in the study. All groups (CIS 0.10 - CIS 0.15 - ROC 0.60 and ROC 0.90, respectively) were comparable with regard to sex, age, weight, height, BSA, BMI, and ASA classification (Tab. 1). No complications attributable to the study or anaesthesia were observed. The pharmacodynamic findings related to neuromuscular block are summarized in Tab. 2 and 3. Following induction of the block, both ROC doses provided the fastest onset time with lowest variability. Clinical duration of the block was dose dependent in both groups, being 42 (SD 7) and 52 (7) min, respectively, for CIS groups and 35 (SD 11) and 52 (12) min, respectively, for ROC groups. During spontaneous recovery, the recovery index was almost uniform for all four groups and the same applies when the blockade was antagonized with neostigmine. The course of complete recovery from the block
(DUR25-TOF90 interval) was more consistent with lower variability in both CIS groups.

\section{DISCUSSION}

Neuromuscular block is an essential part of balanced general anaesthesia. However, widespread use of muscle relaxants, often based on empiricism and superficial look at the commercial information, is frequently associated with unacceptably high incidence of adverse effects. Basically, two categories of potential complications related to the use of neuromuscular blockers can be identified:

1. Adverse effects that are undesirable under any circumstance (e.g. histamine liberation, anaphylactoid or anaphylactic reaction $\left.{ }^{10}\right)$.

2. Adverse reactions caused by increased effect (e.g. improper dosage) and/or by incorrect timing (e.g. postoperative residual curarization).

The incidence of anaphylactic and anaphylactoid reactions occurring during anaesthesia is estimated between 1 in 10,000 and 1 in 20,000 anaesthesias ${ }^{10}$. Neuromuscular blocking agents represent the most frequently involved 
substances ${ }^{10}$, with a range of $50 \%$ to $70 \%$. Rocuronium $(43.1 \%)$ and succinylcholine $(22.6 \%)$ are the most frequently incriminated $\mathrm{NMBs}{ }^{10-16}$. Compared to atracurium, the risk of histamine release following cisatracurium is markedly reduced but sporadic reports on anaphylactic reactions are available ${ }^{17}$. In our study, there were no signs of anaphylaxis during anaesthesia. However, the number of patients studied was too small to draw conclusions.

The ease of intravenous injection of muscle relaxant, resulting in neuromuscular block, contrasts with clinically serious consequences following its application and with considerable interindividual variability. Particularly at the end of anaesthesia, this may present a problem; in one patient, the effect of a single bolus dose of NMB may have fully subsided, while in the other one, there is a significant degree of block still present ${ }^{18-20}$.

The only solution for this potentially life-threating condition is adequate perioperative neuromuscular monitoring ${ }^{21-23}$.

Today, rocuronium is a non-depolarizer with the fastest onset. In this study, the onset times of equipotent doses were three times longer for CIS than for ROC. From this point of view, ROC is superior to CIS (and to any nondepolarizing NMB available today, too) and with special precautions, it can safely be used for rapid sequence induction ${ }^{924-26}$. Fast onset, flexibility and promptness of response make ROC also suitable for a computer-controlled closed-loop system for automatic regulation of neuromuscular block during anaesthesia ${ }^{27}$.

As far as the clinical duration until $25 \%$ recovery is concerned, there was a significant difference both between CIS $0.10 v s$. CIS 0.15 and ROC 0.60 vs. ROC 0.90, respectively. When comparing the equipotent doses of the two relaxants, the clinical duration following lower doses (CIS $0.10 v s$. ROC 0.6) was different (42 (SD 7) vs. 35 (11) min, respectively) but no significant difference could be demonstrated for the larger ones (CIS 0.15 vs. ROC 0.90) $\left(\right.$ ref. $\left.^{28,29}\right)$.

Both NMBs had identical recovery indices, irrespective of the dose administered. This applied both to spontaneous and induced recovery. It means, when the muscle strength recovered to $25 \%$, further course and subsiding of the block was fairly uniform ${ }^{29,30}$. The DUR25-TOF90 interval reflects the time necessary for the complete recovery from the neuromuscular block. Following neostigmine administration, this interval was identical for all four groups $^{30,31}$. When allowing for spontaneous recovery, the variability of this index was twice as great for ROC than for CIS.

Based on the dose administered, the course of recovery was better predicted for CIS than ROC. This may be advantageous at the end of anaesthesia when considering neostigmine administration to prevent postoperative residual curarization ${ }^{17,31-33}$.

\section{CONCLUSION}

ROC is unbeatable in its onset speed. In both doses, it produced fast and deep neuromuscular blockade. For equipotent doses, the onset times for CIS were approximately three times longer than for ROC. Both relaxants provided adequate blockade of average clinical duration ranging from 35 to $52 \mathrm{~min}$ with acceptable variability. In all groups, neostigmine administration accelerated the recovery and decreased its variability. When allowing for spontaneous recovery, less scatter was demonstrated for both CIS groups than for ROC ones.

\section{ACKNOWLEDGEMENTS}

This study was supported by the Czech Ministry of Health Internal Grant Agency - project ND7665-3/2003. The authors express their sincere thanks to Josef Zakravsky (Hoyer, Prague) and Vladimir Srek (Fresenius Medical Care, Czech Republic) for technical assistance.

\section{REFERENCES}

1. Iwasaki H. An overview of the pharmacokinetics and pharmacodynamics of rocuronium bromide. Masui 2006; 55:826-33.

2. Herold I. Muscle relaxants in anaesthesiology and intensive care medicine (in Czech). $1^{\text {st }}$ ed. Prague: Maxdorf; 2004.

3. Evers AS, Maze M. Anesthetic Pharmacology. Physiological Principles and Clinical Practice: A Companion to Miller's Anesthesia. $1^{\text {st }}$ ed. Philadelphia, Pennsylvania: Elsevier; 2004.

4. Mallampati SR, Gatt SP, Gugino LD, Desai SP, Waraksa B, Freiberger D, Liu PL. A clinical sign to predict difficult tracheal intubation: a prospective study. Can Anaesth Soc J 1985; 32:42934.

5. References and formulas used by the Body Surface Area Calculator. Formula for Body Mass Index. Formulas for Body Surface Area [on line] [cited 2006 Sept 18]. Available from http://www.halls. md/body-surface-area/refs.htm

6. Servin F, Cazalaa JB, Levron JC. Propofol, Sufentanil, Remifentanil in TCI. Bibliographical study of anesthetic agents used in the Base Primea $^{\circledR}$, Fresenius Vial. Le Grand Chemin, Brezins: Fresenius Vial, 2003.

7. Viby-Mogensen J, Engbaek J, Eriksson LI, Gramstad L, Jensen E, Jensen FS. Good Clinical Research Practice (GCRP) in pharmacodynamic studies of neuromuscular blocking agents. Acta Anaesthesiol Scand 1996; 40:59-74.

8. Viby-Mogensen J, Ostergaard D, Donati F, Fisher D, Hunter J, Kampmann JP. Pharmacokinetic studies of neuromuscular blocking agents: Good Clinical Research Practice (GCRP). Acta Anaesthesiol Scand 2000; 44:1169-90.

9. Adamus M, Adamus P, Belohlavek R, Vujcikova M, Janaskova E. The impact of different rocuronium doses on its pharmacodynamic profile: a prospective study. Anest Intenziv Med 2004; 15:26975.

10. Mertes PM, Laxenaire MC, Alla F. Anaphylactic and anaphylactoid reactions occurring during anesthesia in France in 1999-2000. Anesthesiology 2003; 99:536-45.

11. Baillard C, Korinek AM, Galanton V et al. Anaphylaxis to rocuronium. Br J Anaesth 2002; 88, 600-2.

12. Brozovic G, Kvolik S. Anaphylactic reaction after rocuronium. Eur J Anaesthesiol 2005; 22:72-3.

13. Harboe T, Guttormsen AB, Irgens A, Dybendal T, Florvaag E. Anaphylaxis during anesthesia in Norway: a 6-year single-center follow-up study. Anesthesiology 2005; 102:897-903. 
14. Bhananker SM, O’Donnell JT, Salemi JR, Bishop MJ. The risk of anaphylactic reactions to rocuronium in the United States is comparable to that of vecuronium: an analysis of food and drug administration reporting of adverse events. Anesth Analg 2005; 101:819-22.

15. Laake JH, Rottingen JA. Rocuronium and anaphylaxis-a statistical challenge. Acta Anaesthesiol Scand 2001; 45:1196-1203.

16. Watkins J. Incidence of UK reactions involving rocuronium may simply reflect market use. Br J Anaesth 2001; 87:522.

17. Lagneau F, Corda B, Marty J. Possible underestimation of the relative incidence of anaphylactic reactions to benzylisoquinoline neuromuscular blocking agents. Eur J Anaesthesiol 2003; 20:577-8.

18. Baillard C, Gehan G, Reboul-Marty J, Larmignat P, Samama CM, Cupa M. Residual curarization in the recovery room after vecuronium. Br J Anaesth 2000; 84:394-5.

19. Cammu G, de Baerdemaeker L, den Blauwen N, de Mey JC, Struys M, Mortier E. Postoperative residual curarization with cisatracurium and rocuronium infusions. Eur J Anaesthesiol 2002; 19:129_ 34.

20. Beaussier M, Boughaba MA. Residual neuromuscular blockade. Ann Fr Anesth Reanim 2005; 24:1266-74.

21. Viby-Mogensen J. Postoperative residual curarization and evidencebased anaesthesia. Br J Anaesth 2000; 84:301-3.

22. Gatke MR, Viby-Mogensen J, Rosenstock C, Jensen FS, Skovgaard LT. Postoperative muscle paralysis after rocuronium: less residual block when acceleromyography is used. Acta Anaesthesiol Scand 2002; 46:207-13.

23. Kopman AF, Zank LM, Ng J, Neuman GG. Antagonism of cisatracurium and rocuronium block at a tactile train-of-four count of 2: should quantitative assessment of neuromuscular function be mandatory? Anesth Analg 2004; 98:102-6.

24. Sluga M, Ummenhofer W, Studer W, Siegemund M, Marsch SC. Rocuronium versus succinylcholine for rapid sequence induction of anesthesia and endotracheal intubation: a prospective, randomized trial in emergent cases. Anesth Analg 2005; 101:1356-61.
25. Perry J, Lee J, Wells G. Rocuronium versus succinylcholine for rapid sequence induction intubation. Cochrane Database Syst Rev 2003, (1):CD002788.

26. Ortiz-Gomez JR, Carrascosa F, Perez-Cajaraville JJ, Percaz-Bados JA, Anez C. Comparative study of intubating conditions at the first minute with suxamethonium, rocuronium and different priming techniques of rocuronium. Eur J Anaesthesiol 2005; 22:263-8.

27. Adamus M, Belohlavek R. Fuzzy control of neuromuscular block during general anesthesia - system design, development and implementation. International Journal of General Systems 2006; to appear.

28. Melloni C, Devivo P, Launo C, Mastronardi P, Novelli GP, Romano E. Cisatracurium versus vecuronium: a comparative, double blind, randomized, multicenter study in adult patients under propofol/ fentanyl/N2O anesthesia. Minerva Anestesiol 2006; 72:299-308.

29. Hans P, Welter P, Dewandre PY, Brichant JF, Bonhomme V. Recovery from neuromuscular block after an intubation dose of cisatracurium and rocuronium in lumbar disc surgery. Acta Anaesthesiol Belg 2004; 55:129-33.

30. Naguib M, Riad W. Dose-response relationships for edrophonium and neostigmine antagonism of atracurium and cisatracurium-induced neuromuscular block. Can J Anaesth 2000; 47:1074-81.

31. Jellish WS, Brody M, Sawicki K, Slogoff S. Recovery from neuromuscular blockade after either bolus and prolonged infusions of cisatracurium or rocuronium using either isoflurane or propofolbased anesthetics. Anesth Analg 2000; 91:1250-5.

32. Debaene B, Plaud B, Dilly MP, Donati F. Residual paralysis in the PACU after a single intubating dose of nondepolarizing muscle relaxant with an intermediate duration of action. Anesthesiology 2003; 98:1042-8.

33. Hayes AH, Mirakhur RK, Breslin DS, Reid JE, McCourt KC. Postoperative residual block after intermediate-acting neuromuscular blocking drugs. Anaesthesia 2001; 56:312-8. 